\title{
Microhabitats and oribatid fauna: comparison of 2 sampling approaches
}

\author{
PIOTR SKUBAŁA \\ University of Silesia, Department of Ecology, Bankowa 9, 40-007 Katowice, Poland \\ Corresponding author: Piotr Skubała, piotr.skubala@us.edu.pl
}

(Received on 21 December 2015; Accepted on 14 March 2017)

\begin{abstract}
Oribatid fauna highly varies among habitats, but different microhabitats within a habitat are also characterized by different mite species. The main goal of the research was to compare the observed structure of an oribatid community when samples were collected at random from the soil-litter layer of $0-10 \mathrm{~cm}$ in depth (standard approach) and selectively from 6 types of available microhabitats (complex approach). Samples were taken within a small plot $(10 \mathrm{~m} \times 10 \mathrm{~m})$ in a forested area of the Silesian Park (Chorzów, south Poland). Overall, 2642 specimens of Oribatida belonging to 62 species were collected in 66 samples. The structure of the oribatid community observed by means of the 2 sampling approaches was completely different. The abundance and species richness of oribatid mites collected from 6 microhabitats were significantly higher than in the soil-litter layer alone. Results of this study show that random collecting of only soil-litter samples may reduce the evaluation of species richness in a study area by $40 \%$. Each of the studied microhabitats supported a peculiar oribatid fauna.
\end{abstract}

Keywords: microhabitat, Oribatida, community structure, sampling approaches

\section{INTRODUCTION}

The soil biodiversity has been described as "the poor man's tropical rainforest" (UsHer et al. 1982). More than any other habitat, it is the province of mites, especially oribatids (WALTER \& PROCTOR 1999). In the upper $10 \mathrm{~cm}$ of soil, usually between 50000 and $250000 \mathrm{mites} / \mathrm{m}^{2}$ exist (PETERSEN 1982). Oribatid mites inhabit a wide range of soil types or habitats, with numerous species, and their different communities indicate environmental qualities. Different oribatid communities are recognized in coniferous, deciduous or mixed forests, hay or wet meadows, and farmland.

To characterize the structure of soil mite communities, in the standard approach, researchers collect samples at random from the soil-litter layer to the depth of $5 \mathrm{~cm}$ or more, usually up to $10 \mathrm{~cm}$ (e.g. NiedBata et al. 1982; Koenler \& Born 1989; Schaefer \& Schauermann 1990; Weigmann 1991; Sylwestrowicz-Maliszewska et 
al. 1993; Seniczak et al. 1998; Hubert 1999; KaneKo et al. 2005). However, the oribatid fauna within a habitat is varied and different microhabitats are inhabited by different mite species. It is noteworthy that in a forest, oribatid mites inhabit not only the soil-litter layer, but also dead wood of various forms, mosses (growing on logs, standing trees or rocks), fungal fruiting bodies, grasses, tree bark, fallen twigs and tree hollows (Aoki 1967; Seyd \& Seaward 1984; Wunderle 1992; Behan-Pelletier \& Walter 2000; Materna 2000; Root et al. 2007; Sirra-Pietikäinen et al. 2008). Each of these microhabitats has distinct characteristics, including abiotic factors and biotic interactions, which enable the establishment of specific mite communities (WEHNER et al. 2016). Already in the 1970s, Anderson (1978a, b) showed that the diversity of soil mites increased with microhabitat diversity. FuJIKAWA (1970) remarked that the more various organic matter is accumulated in a studied area, the more complicated its oribatid fauna becomes. Several authors also suggested that microhabitat diversity is correlated closely with the diversity of oribatid mites (AOKI 1967; HAMMER 1972; ANDERSON 1978a).

The primary aim of this project was to compare the observed structure of an oribatid community when samples were collected in 2 different ways. In the standard approach, soil-litter samples were collected randomly in a square plot $10 \mathrm{~m} \times 10 \mathrm{~m}$. In the complex approach, samples were taken selectively in 6 types of microhabitats in the same area. The study was aimed to answer the following questions:

1. Which of the sampling approaches generates a complete picture of the structure of an oribatid community?

2. What part of the species richness of oribatid fauna is omitted if only soil-litter samples are taken randomly?

3. Which of the sampled microhabitats is characterized by the highest abundance and diversity of mites?

4. To what extent does the oribatid fauna differ between microhabitats?

\section{MATERIAL AND METHODS}

\section{Study area}

The investigation was performed in the Silesian Park located in Chorzów (Silesian province, south Poland; 50 $29^{\prime} \mathrm{N}, 1^{\circ} 98^{\prime} \mathrm{E}$ ), in its forest section. Until the early $1950 \mathrm{~s}, 75 \%$ of this area was a huge wasteland covered in mining slag heaps, other mining wastes, bootleg mines, cave-ins, marshes and garbage dumps, while only a small section was used as farmland. To restore the natural environment, about 3.5 million $\mathrm{m}^{3}$ of highly polluted soil was removed and replaced by 0.5 million $\mathrm{m}^{3}$ of fertile soil and turf. Thanks to this, the degraded landscape quickly turned into about 600 hectares of meadows, forests, gardens, and flower beds, with ponds, streams, and clumps of rare trees and bushes, supporting diverse wildlife. For more than 60 years the Silesian Park has been admired as an unsurpassed oasis of green within the Silesian agglomeration, i.e. in Poland's most industrialized and populated region. It is the largest city park of this type in Europe. 


\section{Sample collection and sampling design}

A quadrat $(10 \mathrm{~m} \times 10 \mathrm{~m})$ was set up in a forested section of the Park. In the standard approach, 30 random soil-litter samples $(0-10 \mathrm{~cm}$ in depth) were taken using a stainless steel corer of $4.8 \mathrm{~cm}$ in diameter. In the complex approach, within the same quadrat, 36 samples (6 samples per microhabitat) were collected from 6 microhabitats: soil-litter $(0-10 \mathrm{~cm})$, moss (common haircap moss Polytrichum commune), fungus (hoof fungus Fomes fomentarius), dead wood (lying log, $3^{\text {rd }}$ stage of decomposition), leaves collected from the ground (mainly of maple Acer platanoides), and a tree hollow (at the height of $1 \mathrm{~m}$, in a maple tree). In total, 66 samples were collected. Sampling was done in autumn (28 October 2013) and in spring (2 June 2014). The stage of decomposition of the logs was described using a 5-degree scale based on PYLE \& BRown's (1998) classification.

Oribatid mites were extracted from the samples using the Tullgren method (MACFADYEN 1961). The samples were placed on an extractor for 6 days or until a sample was thoroughly dried. Oribatid mites were first preserved in alcohol (60-70\%) and later mounted on temporary microscopic slides with lactic acid and identified using a light microscope and determination keys: Weigmann (2006), NiedbaŁA (2008), and OlszANOWSKi (1996). Because of difficulties in associating juvenile and adult oribatids, juveniles were counted but were not assigned to species. The systematic classification proposed by SubíAs (2004-2015) was followed. The distribution of oribatid species in different microhabitats is listed in Appendix I.

\section{Statistical analysis}

Four univariate measures were used to assess community structure: abundance per $100 \mathrm{~g}$ dry weight (DW), total and mean number of species per sample, and the Shannon diversity index $\left(\log _{\mathrm{e}}\right)$. Shannon indices $(x)$ were transformed to "true diversities" by $\exp (x)$ following Jost (2006), which reduces the sensitivity to common and rare species. The Mann-Whitney $U$ test was used to test for differences between soil-litter samples and pooled samples from microhabitats in abundance, species richness, and diversity of oribatid mites. The nonparametric Kruskal-Wallis test was performed to reveal significant differences in different characteristics of mite diversity between 6 microhabitats. If the Kruskal-Wallis test was positive, then a test for pairwise comparison of microhabitats was used. The level of significance for all statistical tests was accepted at $\alpha=0.05$.

Permutational multivariate analysis of variance (PERMANOVA) was performed to test for differences among microhabitats in terms of oribatid species composition (ANDERSON 2001), together with post-hoc pairwise comparisons between particular sampling sites. All species were included in the analysis. The analysis was based on the matrix of species abundance in particular sites by using the Bray-Curtis coefficient with 1000 permutations for each test. Non-metric multidimensional scaling (NMDS) was used to find a pattern of similarities between microhabitats in terms of oribatid species composition (TAGUCHI \& OONO 2005). The analysis was performed using the Bray-Curtis coefficient.

Detrended correspondence analysis (DCA) was chosen as the ordination method to explore the compositional variation between microhabitats. The interpretation was 
restricted to the ordination space determined by the first 2 axes. To avoid an excessive amount of noise in the data matrix, which could obscure some data features, all species present as singletons were removed from the analysis, because they did not improve the DCA analysis and this was confirmed in an initial analysis with all species. The numbers of individuals were $\log (x+1)$ transformed and equal weight was applied to all species. All statistical calculations for this research were done in STATISTICA 12 (Statsoft Inc., Tulsa, USA) and PAST 3.10 software (HAMMER et al. 2001).

\section{RESULTS}

Overall, 2642 specimens of Oribatida belonging to 62 species were collected in 66 samples. The abundance of oribatid mites in soil-litter samples was about 38 individuals per $100 \mathrm{~g} \mathrm{DW}$. It was significantly higher in pooled samples taken from 6 microhabitats $(U=1.545, p=0.0000)$. As regards adult and juvenile forms, the differences were also statistically significant, but the proportion of juveniles in microhabitats was not as large as for adults (Table 1). The total number of oribatid species recorded in the complex approach was much higher (59) than in soil-litter samples alone (38). In contrast, the mean number of species per sample was significantly higher in soil-litter samples. Similarly, the Shannon diversity was higher in soil-litter samples than in selectively collected samples from microhabitats (Table 1). Differences in the observed species structure of the oribatid community were also very clear. In total, 62 oribatid species were recorded in the study and 34 species $(55 \%)$ were common to soil-litter and other microhabitats. The number of exclusive species for soil-litter samples was very low (4 species), whereas the number of such species in microhabitats was high ( 24 species, $41 \%$ of the total in the complex approach). All dominant species collected in soil-litter samples were also observed in microhabitats, but their proportion was very small in mosses, dead wood, tree hollows, hoof fungus, and leaves. For example, Conchogneta willmanni constituted over $10 \%$ of all mites in soil-litter samples, whereas its proportion in microhabitats was 10-fold lower (Table 1). In contrast, dominant oribatid species in microhabitats - Tectocepheus alatus, Carabodes (C.) femoralis, and Damaeus (Epidamaeus) bituberculatus - were not observed in soil-litter samples (Table 1).

The highest abundance of total oribatids was observed in samples of mosses. The abundance in microhabitats was differentiated, but there were no statistically significant differences among the 6 studied microhabitats. Only in the soil-litter layer, oribatid abundance was low and the differences were statistically significant in relation to the other microhabitats. These relationships were the same for the adult forms. As regards juveniles, there were no statistically significant differences among the 6 studied microhabitats (Table 2). The total number of species was the highest in mosses and the lowest in the tree hollow. The mean number of species per sample was the highest in leaves, slightly lower in mosses, fungus and the soil-litter layer, and the lowest in dead wood. However, the differences in mean number of species per sample were not statistically significant. The moss layer differed from all the other microhabitats by housing the highest number of exclusive species (10), which did not occur anywhere else in the study area. In contrast, there was no exclusive species in 
Table 1. Abundance (individuals per $100 \mathrm{~g} \mathrm{DW} \pm \mathrm{SE}$ ) and diversity of oribatid mites and dominance index of most abundant species collected from the soil-litter layer (standard approach) and 6 microhabitats (complex approach) in the Silesian Park. Differences between the 2 approaches verified by the Mann-Whitney $U$ test $(p=0.05)$

\begin{tabular}{|c|c|c|c|c|}
\hline \multirow{2}{*}{ Parameter } & \multirow[t]{2}{*}{ Soil-litter } & \multirow[t]{2}{*}{ Microhabitats } & \multicolumn{2}{|c|}{ Mann-Whitney test } \\
\hline & & & $U$ & $p$ \\
\hline Abundance of total Oribatida & $37.9 \pm 4.2$ & $817.6 \pm 233.8$ & 154.5 & $<0.0001$ \\
\hline Abundance of Oribatida adults & $30.6 \pm 3.7$ & $762.4 \pm 232.6$ & 154.5 & $<0.0001$ \\
\hline Abundance of Oribatida juv. & $7.3 \pm 1.1$ & $55.1 \pm 11.8$ & 313.5 & 0.0036 \\
\hline Total no. of species & 38 & 59 & & \\
\hline Mean no. of species per sample & $12.1 \pm 0.7$ & $7.5 \pm 0.6$ & 195.5 & $<0.0001$ \\
\hline Shannon diversity index & $10.07 \pm 0.56$ & $5.23 \pm 0.43$ & 126.5 & $<0.0001$ \\
\hline \multirow[t]{2}{*}{ Species } & \multicolumn{2}{|c|}{ Dominance index (\%) } & & \\
\hline & Soil-litter & Microhabitats & & \\
\hline Phthiracarus (P.) ferrugineus & 13.4 & 2.6 & & \\
\hline Atropacarus striculus striculus & 13.0 & 3.6 & & \\
\hline Conchogneta willmanni willmanni & 10.2 & 1.0 & & \\
\hline Phthiracarus (P.) longulus & 7.7 & 0.3 & & \\
\hline $\begin{array}{l}\text { Phthiracarus (Archiphthiracarus) } \\
\text { globosus }\end{array}$ & 6.3 & 0.1 & & \\
\hline Tectocepheus alatus & - & 25.8 & & \\
\hline Carabodes (C.) femoralis & - & 17.5 & & \\
\hline $\begin{array}{l}\text { Damaeus (Epidamaeus) } \\
\text { bituberculatus }\end{array}$ & - & 5.1 & & \\
\hline
\end{tabular}

Bold values denote significant differences in abundance or species richness at $p<0.05$.

hoof fungus samples. The "true diversity" significantly differed among the studied microhabitats. It was the highest in leaves and soil-litter samples and the lowest in the tree hollow (Table 2, Appendix I).

NMDS ordination shows similarities of the 6 studied microhabitats in terms of oribatid species composition (Fig. 1). The samples are rather evenly scattered, but the separation of certain microhabitats is well visible. The samples from the tree hollow (right-hand side) and soil-litter (left-hand side) are clearly separated along the first axis. The samples of moss and fungus (lower part) and dead wood and leaves (upper part) are also comparatively well separated along axis 2. Oribatid species composition varies significantly among the studied microhabitats (PERMANOVA; $F=2.369, p=0.0001)$. Pairwise comparisons reveal significant differences between 


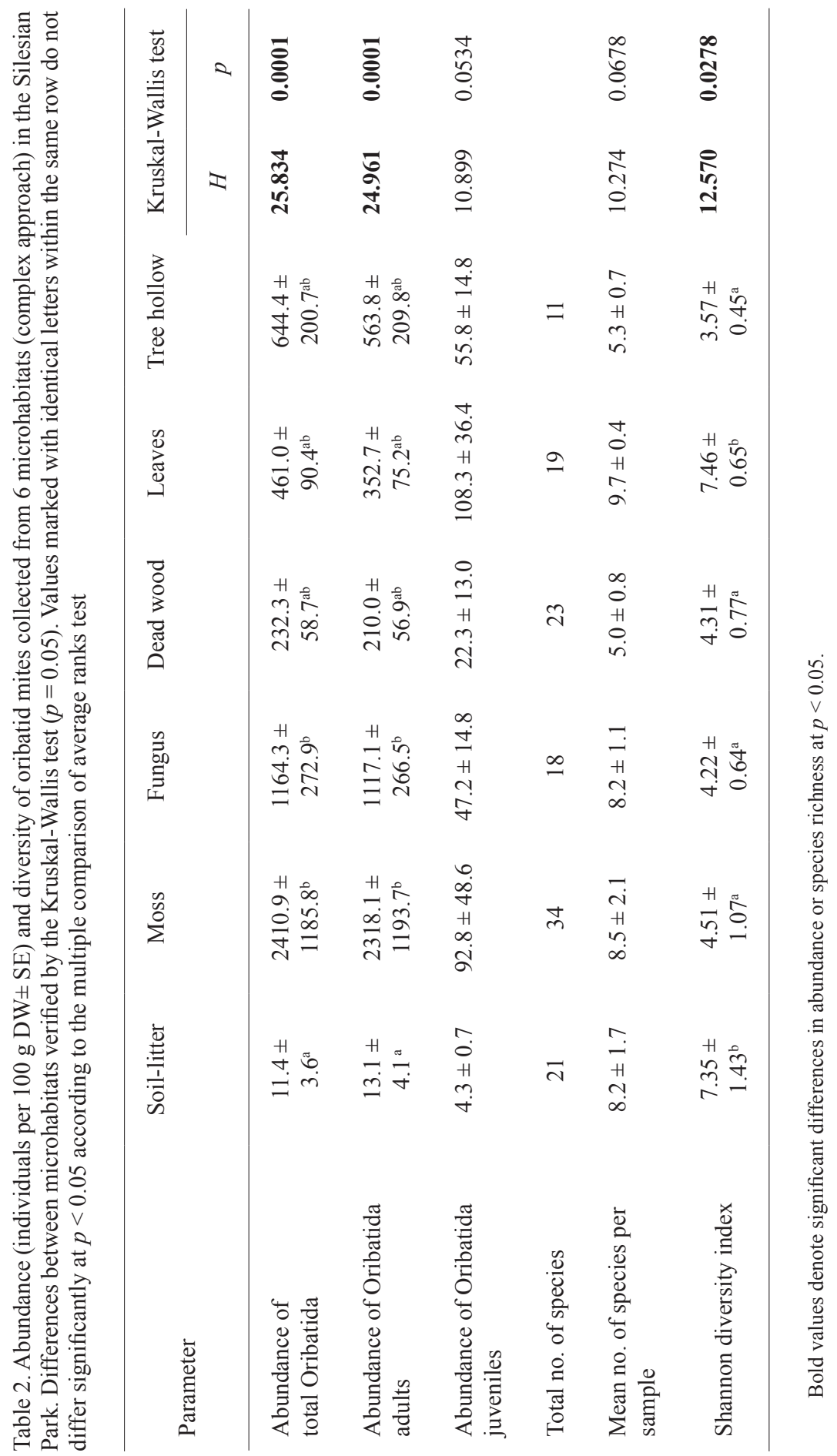




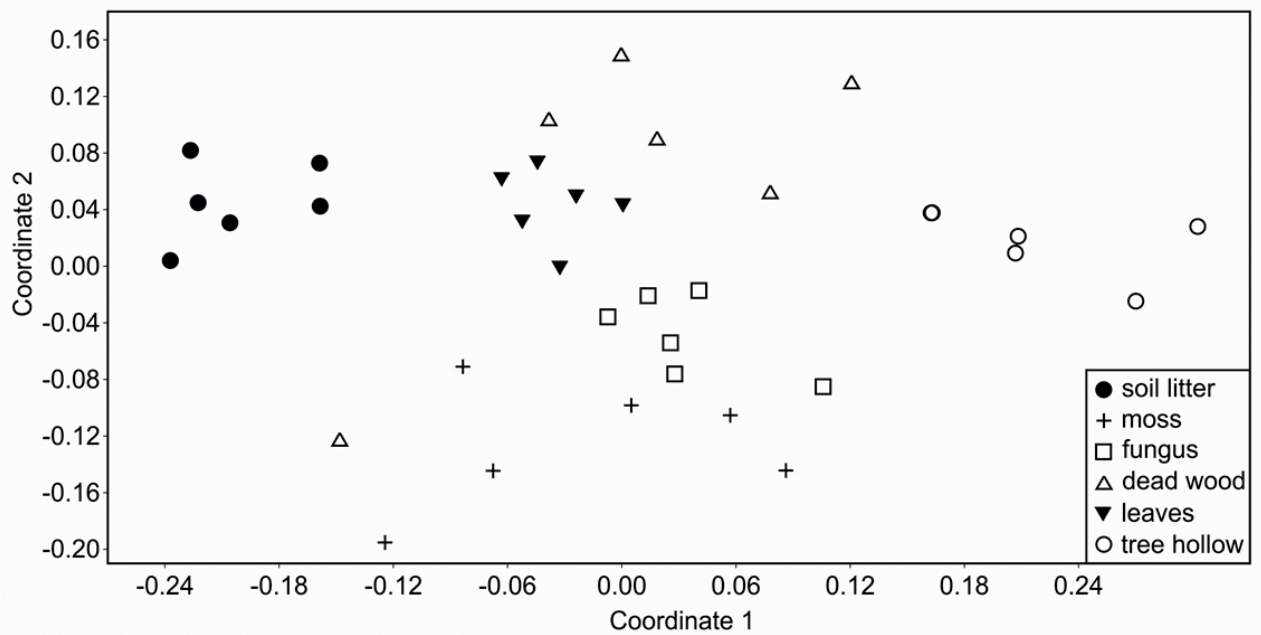

Fig. 1. The non-metric multidimensional scaling (NMDS) scatterplot of samples representing 6 microhabitats in the Silesian Park in terms of oribatid species composition

some microhabitats. The tree hollow is the most distinct in terms of species composition since it differs significantly from all the other microhabitats (PERMANOVA; $\mathrm{p}<0.05)$. The soil-litter layer differs significantly from nearly all microhabitats, with the exception of dead wood. The remaining microhabitats do not differ significantly from each other, with the exception of a significant difference between dead wood and fungus $(p=0.02)$.

Ordination by DCA was used to assess similarities among oribatid fauna in the 6 microhabitats. The eigenvalue (the dispersion of the sites/species distribution along the ordination axis) of the first and second axis are $\lambda_{1}=0.862$ and $\lambda_{2}=0.564$, respectively. The first 2 axes explain over $53 \%$ of the total variance. Four dominant species - D. bituberculatus, Oppia nitens nitens, Subiasella (Lalmoppia) quadrimaculata, and Ramusella (Rectoppia) fasciata fasciata - can be regarded as associated with dead wood of the tree hollow (right part of axis 1) (Table 3, Fig. 2). Axis 2 describes a gradient that separates the oribatid mites of hoof fungus samples. Two dominant species are strongly associated with this microhabitat: $C$. femoralis and Hafenrefferia gilvipes. The differences in oribatid fauna between the 4 other microhabitats are not so strong, but still present. Two dominants - Quadroppia (Q.) quadricarinata and Acrotritia duplicate - can be regarded as characteristic of dead wood of lying logs. Tectocepheus alatus was very abundant in mosses. It constituted almost $60 \%$ of the total number of oribatids in this microhabitat. Many species reached a high abundance in samples of the soil-litter layer and leaves: Atropacarus striculus striculus, Phthiracarus (P.) ferrugineus, and Conchogneta willmanni willmanni. They domi- 
nated in the oribatid fauna in both the microhabitats, but the first 2 species were also dominants in dead wood (Table 3, Fig. 2).

Table 3. Dominance index (\%) of dominant oribatid species collected in microhabitats in the Silesian Park. Values over 5.0\% are in bold

\begin{tabular}{|c|c|c|c|c|c|c|}
\hline \multirow{2}{*}{ Species } & \multicolumn{6}{|c|}{ Dominance index $(\%)$} \\
\hline & $\begin{array}{l}\text { Soil- } \\
\text { litter }\end{array}$ & Moss & Fungus & $\begin{array}{l}\text { Dead } \\
\text { wood }\end{array}$ & Leaves & $\begin{array}{c}\text { Tree } \\
\text { hollow }\end{array}$ \\
\hline Atropacarus striculus striculus & 14.6 & 4.6 & 0.2 & 11.2 & 12.6 & - \\
\hline Phthiracarus (P.) ferrugineus & 13.2 & 1.6 & 2.7 & 11.2 & 7.7 & - \\
\hline $\begin{array}{l}\text { Conchogneta willmanni } \\
\text { willmanni }\end{array}$ & 10.6 & 0.9 & - & - & 7.3 & - \\
\hline Oppiella $(O$.$) nova nova$ & 8.7 & 6.7 & 3.8 & - & - & - \\
\hline Rhinoppia $(R$.) subpectinata & 8.1 & - & - & - & - & - \\
\hline Acrotritia ardua ardua & 6.7 & & 0.3 & & 2.0 & \\
\hline Rhinoppia (R.) obsoleta obsoleta & 5.9 & - & - & - & - & - \\
\hline $\begin{array}{l}\text { Phthiracarus } \\
\text { (Archiphthiracarus) globosus }\end{array}$ & 5.1 & - & - & 1.5 & - & - \\
\hline Tectocepheus alatus & - & 58.7 & 1.1 & - & - & - \\
\hline Xenillus $(X$.$) tegeocranus$ & - & 8.5 & 0.9 & - & 12.9 & 1.0 \\
\hline Carabodes $(C$.) femoralis & - & 3.4 & 62.9 & - & 3.4 & - \\
\hline Hafenrefferia gilvipes & - & 1.7 & 15.8 & 2.7 & - & - \\
\hline Quadroppia $(Q$.$) quadricarinata$ & - & 0.2 & - & 21.7 & - & - \\
\hline $\begin{array}{l}\text { Quadroppia } \\
\text { (Coronoquadroppia) michaeli } \\
\text { michaeli }\end{array}$ & - & 2.5 & - & 7.9 & 2.2 & - \\
\hline Acrotritia duplicata & - & - & - & 5.7 & - & - \\
\hline Nothrus anauniensis & 0.9 & 0.4 & - & - & 18.1 & - \\
\hline Tectocepheus velatus velatus & 2.0 & 0.3 & 0.2 & 0.6 & 6.2 & - \\
\hline Ceratozetes $(C$.$) gracilis gracilis$ & 2.9 & 0.3 & - & - & 6.0 & - \\
\hline Euzetes globulus & 1.0 & - & - & 1.5 & 5.9 & - \\
\hline $\begin{array}{l}\text { Damaeus (Epidamaeus) } \\
\text { bituberculatus }\end{array}$ & - & - & - & 1.5 & - & 38.0 \\
\hline Oppia nitens nitens & - & - & - & - & - & 30.5 \\
\hline $\begin{array}{l}\text { Subiasella (Lalmoppia) } \\
\text { quadrimaculata }\end{array}$ & - & 1.7 & - & - & - & 8.8 \\
\hline $\begin{array}{l}\text { Ramusella (Rectoppia) fasciata } \\
\text { fasciata }\end{array}$ & - & - & - & - & - & 5.3 \\
\hline
\end{tabular}




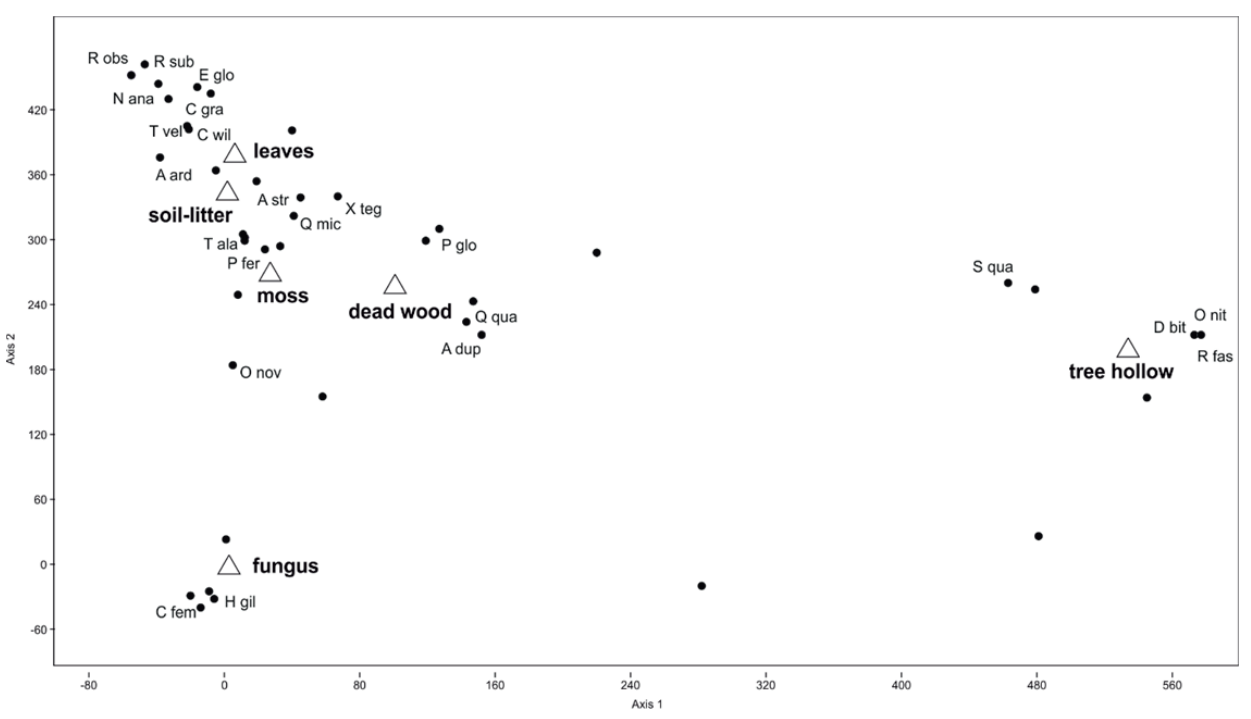

Fig. 2. The biplot of the first 2 axes of the detrended correspondence analysis (DCA) of 6 microhabitats in the Silesian Park. The abbreviations of dominant species (which constitute $5 \%$ or more of the total number of individuals within the different microhabitats) are shown in the graph. See Appendix I for full species names of dominants

None of the species were common to all the studied microhabitats. As regards dominant species, only A. striculus, P. ferrugineus, and Tectocepheus velatus velatus were recorded in 5 of the microhabitat types. Some species were noted in only one of microhabitats, e.g. Rhinoppia (R.) subpectinata and Rhinoppia (R.) obsoleta obsoleta in the soil-litter layer, A. duplicata in dead wood, while $O$. nitens and $R$. fasciata in the tree hollow (Table 3, Appendix I).

\section{DISCUSSION}

The observed structure of the oribatid community based on soil-litter samples taken randomly is completely different from that based on samples collected selectively from 6 available microhabitats within the study area. The abundance and species richness of oribatid mites in the soil-litter layer were significantly lower than in the pooled sample from microhabitats. None of the dominant oribatid species in microhabitats (T. alatus, C. femoralis and D. bituberculatus) were recorded in soillitter samples. As many as 24 species $(41 \%$ of the total number) noted in different microhabitats were not found in samples from the soil-litter layer. It means that if samples are not collected from all available microhabitats in a study area (in this study, a small plot $10 \mathrm{~m} \times 10 \mathrm{~m}$ ), evaluation of species richness could be reduced by $40 \%$. However, it should be noted that when we evaluate the structure of the oribatid 
community based on samples from the soil-litter layer, it is more stable. The mean number of species per sample and "true diversity" are significantly higher in soillitter samples compared to pooled microhabitat data. The proportions of individual species (e.g. dominants) are more even in soil-litter samples, whereas in pooled microhabitat data the proportion of the dominant species is very high. It is a well-known phenomenon that forest soils are characterized by relatively stable conditions, with narrow fluctuations of moisture, temperature, etc. (MARAun \& SCHEU 2000). It results in a more stable structure of oribatid communities in comparison to those of selected microhabitats.

Some authors have reported that oribatid mites benefit from increased numbers of microhabitats (e.g. Hansen 2000; Eissfeller et al. 2013). AoKi (1967) was the first to call attention to the importance of collecting oribatids from as many different microhabitats as possible and not being content only to collect on the surface of the forest floor or in the soil and avoiding intentionally other microhabitats in the area. Nevertheless, most studies on oribatid mites are still based only on samples from the soil-litter layer. This is understandable, because often the number of microhabitats present in a given area is large and collecting samples from the soil, litter and also all microhabitats would significantly prolong the time of the study. Nevertheless, this should not be a reason for ignoring sampling of all available material.

The oribatid fauna is highly differentiated in the studied microhabitats. Strong dissimilarities in oribatid fauna of microhabitats were revealed by the ordination technique. No species was common to all microhabitats. The highest abundance, species richness, and a high number of exclusive species were observed in the moss layer. However, the structure of the oribatid community in mosses was unstable, with one species (Tectocepheus alatus) constituting almost $60 \%$ of the total number. The presence of abundant and diverse oribatid fauna in mosses is well known in the literature (e.g. Aoki 1974; Borowiak \& Niedbala 1982; Wehner et al. 2016). Many oribatid taxa are adapted to use them for food, shelter, or environmentally constant habitat (GLime 2013). Oribatids do not feed directly on moss material; instead, most species consume mostly the fungi, algae, and bacteria present within the moss (WoLF \& Rocket 1984; SmRž 2010). The relationship between bryophytes and oribatids can be mutualistic. When water is scarce, some mite species can transfer moss sperm, so that mosses reproduce with the help of oribatid mites (CRONBERG et al. 2006).

The most distinct was the fauna of the tree hollow. Three dominant species are representatives of the family Oppidae and the fourth is a small species of the family Damaeidae (D. bituberculatus). Some authors have stressed that a tree hollow has its own biota (Park \& Auerbach 1954; Ranius 2001). Skubala \& Gurgul (2011) observed $1 / 4$ of the total number of oribatid species as unique to wood dust in tree hollows.

The abundance of oribatids in soil-litter samples was many times lower than in other microhabitats. However, the stable structure of the oribatid community in the soil-litter layer was characterized by a high proportion of juveniles, high Shannon diversity index, and the highest number (8) of dominant species (their dominance index varied from $5.1 \%$ to $14.6 \%$ ). Two groups of oribatid mites dominated in the soil-litter layer: 4 representatives of the Oppidae and 4 species of ptyctimous mites. Dead wood 
is an important component of forest in the temperate climate. It is a preferred biotope for many oribatid species (SirRa-PietikAinen et al. 2008; SKubata \& MaŚlak 2009; Huhta et al. 2012; SkubaŁa \& Marzec 2013). Dead wood provides unique microclimatic conditions (LACHAT et al. 2012) but only few species occurred exclusively in this microhabitat (SEAstedt et al. 1989; Johnston \& Crossley 1993; Bluhm et al. 2015). However, some authors observed about $40 \%$ of oribatid species as obligate members of the dead wood fauna (SkubaŁa \& SokoŁowska 2006; Skubala \& DuRAS 2008; SkubaŁa \& MaŚlak 2009; SkubaŁa \& Marzec 2013). In this study, a low abundance and comparatively high species richness were observed in dead wood, similarly as in a study by WEHNER et al. (2016) on specialization of oribatid mites adapted to forest microhabitats. Three of the dominant species in this microhabitat were representatives of Phthiracaridae and Eupthiracaridae. The juveniles of those mites burrow in woody substrates until they disperse as adults (WEHNER et al. 2016). Two other dominant species present almost exclusively in this microhabitat were 2 species of the genus Quadroppia.

Relatively high numbers of individuals and species were collected from hoof fungus. However, the presence of 2 species, which constituted almost $80 \%$ of the total number, indicates that the microhabitat is highly unstable and ephemeral. Both dominant species (C. femoralis and H. gilvipes) are strongly sclerotized, typical surface dwellers, well protected against harsh environmental fluctuations. The abundance and species richness of oribatids noted in leaves on the ground were average, similar to those observed in the fungus. However, this microhabitat seems to be more suitable for oribatids, as a high value of "true diversity" and high number of dominants (8), similar to those in the soil-litter layer, were observed in leaves. Among dominants, species of many different oribatid groups can be found.

The differences in oribatid fauna between microhabitats were previously emphasized by some authors. AOKI (1974) observed that each of the studied microhabitats in forest floors contained a peculiar oribatid fauna. The same phenomenon was reported by SMRž et al. (2015) with regard to soil microhabitats in agroecosystems. NIELSEN et al. (2010) provided direct evidence for the hypothesis that small-scale heterogeneity in soils increases the species richness of intermediate-sized soil fauna, including oribatid mites. As regards the litter layer, Hansen \& Coleman (1998) observed that species richness of soil mites increased with the complexity and heterogeneity of this microhabitat. Many oribatid species show strong preferences for specific soil horizons (MitcheLl 1978) or for particular physicochemical conditions within the soil (WAuthy 1982; DuCARME et al. 2004). That may explain such a large variation of oribatid fauna between the studied microhabitats. KARASAWA \& HiJI (2004) emphasized the importance of factors responsible for microhabitat diversity (in that case characterized specifically on flooded trunks of mangrove trees). The cited authors showed that oribatid communities in the same microhabitat at different sites tended to be more similar than those on different microhabitats at the same site.

In view of the above-mentioned results that different microhabitats support different oribatid fauna, it is necessary to sample as many microhabitats as possible to estimate properly the oribatid fauna of a study area. Habitat heterogeneity, i.e. the presence of different microhabitats, is of great importance for species richness of ori- 
batid mites. The corollary of this is that any activity that eliminates microhabitats (e.g. removal of dead wood, treatment of decaying trees) may reduce soil biodiversity.

\section{CONCLUSIONS}

1. Random sampling may lead to an incorrect assessment of the structure of oribatid communities of the studied environment. If we do not collect samples in all available microhabitat types, we can skip up to $40 \%$ of oribatid species present in a given area.

2. Microhabitats seem to provide less stable conditions for oribatid mites (in comparison to the soil-litter layer) but they are characterized by specific oribatid fauna, well adapted to life in the unstable microhabitats.

3 . The richest oribatid community was observed in mosses, whereas the most distinct was the oribatid fauna of the tree hollow.

\section{REFERENCES}

ANDERSON J. M. 1978a. Inter- and intra-habitat relationships between woodland Cryptostigmata species diversity and the diversity of soil and litter microhabitats. Oecologia 32: 341-348.

ANDERSON J. M. 1978b. A method to quantify soil-microhabitat complexity and its application to a study of soil animal species diversity. Soil Biol. Biochem. 10: 77-78.

ANDERSON M. J. 2001. A new method for non-parametric multivariate analysis of variance. Austral Ecol. 26: 32-46.

Aокі J. 1967. Microhabitats of oribatid mites on a forest floor. Bull. National Sci. Mus. Tokyo 10: $133-138$.

AOKI T. 1974. Comparison among oribatid faunas from different microhabitats in forest floors. Appl. Ent. Yool. 9: 105-114.

Behan-Pelletier V., Walter D. 2000. Biodiversity of oribatid mites (Acari: Oribatida) in tree canopies and litter. In: Invertebrates as Webmasters in Ecosystems (Coleman D. C., Hendrix P. F., Eds), pp. 187-202, CAB International, Wallingford.

Bluhm C., Scheu S., Maraun M. 2015. Oribatid mite communities on the bark of dead wood vary with log type, surrounding forest and regional factors. Appl. Soil Ecol. 89: 102-112.

Borowiak P., NiedbaŁa W. 1982. Mikrośrodowiska mechowców (Acari, Oribatei) w dwóch odmiennych wariantach roślinnych zespołu Melico-Fagetum typicum w rezerwacie "Słomowo". [Microhabitats of moss mites (Acari, Oribatei) in two different variants of plant association Melico-Fagetum typicum in the "Słomowo" Reserve] Bad. Fizjog. Pol. Zach. 5C, 33: 39-74 (in Polish).

Cronberg N., Natcheva R., Hedlund K. 2006. Microarthropods mediate sperm transfer in mosses. Science 313: 1255.

Ducarme X., André H. M., Wauthy G. 2004. Are there real endogeic species in temperate forest mites? Pedobiologia 48: 139-147.

Eissfeller V., Langenbruch C., Jacob A., Maraun M., Scheu S. 2013. Tree identity surpasses tree diversity in affecting the community structure of oribatid mites (Oribatida) of deciduous temperate forests. Soil Biol. Biochem. 63: 154-162.

FUJIKAWA T. 1970. Relation between oribatid fauna and some environments of Nopporo National Forest in Hokkaido (Acarina: Cryptostigmata) II. Oribatid fauna in soils under four different vegetations. Appl. Ent. 5: 69-83. 
Glime J. M. 2013. Arthropods: Mites (Acari). In: Bryophyte ecology, vol. 2. Bryological interaction (Glime J. M., Ed.), chapter 9-1, pp. 1-32, E-book sponsored by Michigan Technological University and the International Association of Bryologists.

Hammer M. 1972. Microhabitats of oribatid mites on a Danish woodland floor. Pedobiologia 12: $412-423$.

Hammer Ø., Harper D. A. T., Ryan P. D. 2001. PAST: Paleontological Statistics Software Package for Education and Data Analysis. Palaeontol. Electron. 4: 1-9.

HANSEN R. A. 2000. Effects of habitat complexity and composition on a diverse litter microarthropod assemblage. Ecology 81: 1120-1132.

Hansen R., Coleman D. C. 1998. Litter complexity and composition are determinants of the diversity and species composition of oribatid mites (Acari: Oribatida) in litterbags. Appl. Soil Ecol. 9: 17-23.

HUBERT J. 1999. Oribatid communities (Acari: Oribatida) in the soil on the border of a town. In: Soil Zoology in Central Europe (Tajovský K., PIžI V., Eds), pp. 101-108, ISB AS CR, České Budejovice.

Huhta V., Sirra-Pietikäinen, A., Penttinen R. 2012. Importance of dead wood for soil mite (Acarina) communities in boreal old-growth forests. Soil Organisms 84: 499-512.

Johnston J. M., Crossley D. A. 1993. The significance of coarse woody debris for the diversity of soil mites. In: Proceedings of the Workshop on Coarse Woody Debris in Southern Forests: Effects on Biodiversity (McMinn J. W., Crossley D. A. Eds), pp. 82-87, General Technical Report SE-94. Athens.

Jost L. 2006. Entropy and diversity. Oikos 113: 363-375.

Kaneko N., Sugawara Y., Miyamoto T., Hasegawa M., Hiura T. 2005. Oribatid mite community structure and tree species diversity: A link? Pedobiologia 49: 521-528.

KarasaWA S., Hisi N. 2004. Effects of microhabitat diversity and geographical isolation on oribatid mite (Acari: Oribatida) communities in mangrove forests. Pedobiologia 48: 245-255.

Koenler H., Born H. 1989. The influence of vegetation structure on the development of soil mesofauna. Agr. Ecosyst. Environ. 27: 253-269.

Lachat T., Wermelinger B., Gossner M. M., Bussler H., Isacsson G., Müller J. 2012. Saproxylic beetles as indicator species for dead-wood amount and temperature in European beech forests. Ecol. Indic. 23: 323-331.

MACFADYEN A. 1961. Improved funnel-type extractors for soil arthropods. J. Anim. Ecol. 30: 171-181.

Maraun M., Scheu S. 2000. The structure of oribatid mite communities (Acari, Oribatida): patterns, mechanisms and implications for future research. Ecography 23: 374-383.

Materna J. 2000. Oribatid communities (Acari: Oribatida) inhabiting saxicolous mosses and lichens in the Krkonoše Mts. (Czech Republic). Pedobiologia 44: 40-62.

Mitchell M. J. 1978. Vertical and horizontal distributions of oribatid mites (Acari: Cryptostigmata) in an aspen woodland soil. Ecology 59: 516-525.

Niedbala W. 2008. Ptyctimous mites (Acari: Oribatida) of Poland. Fauna Poloniae, Natura optima dux Foundation, 3: 1-242.

Niedbała W., Błaszak Cz., BŁoszyk J., Kaliszewski M., Każmierski A. 1982. Soil mites (Acari) of Warsaw and Mazovia. Mem. Zool. 36: 235-252.

Nielsen U. N., Osler G. H. R., Campbell C. D., Neilson R., Burslem D. F. R. P., van der Wal R. 2010. The enigma of soil animal species diversity revisited: The role of small-scale heterogeneity. PLoS ONE 5: e11567. doi:10.1371/journal.pone.0011567

OlsZANOWSKi Z. 1996. A monograph of the Nothridae and Camisiidae of Poland (Acari: Oribatida: Crotonioidea). Genus (Supplement): 1-201.

Park O., Auerbach S. I. 1954. Further study of the tree-hole complex with emphasis on quantitative aspects of the fauna. Ecology 35: 208-222.

Petersen H. 1982. Structure and size of soil animal populations. Oikos 39: 306-329.

Pyle C, Brown M. M. 1998. A rapid system of decay classification for hardwood logs of the eastern deciduous forest floor. J. Torrey Bot. Soc. 125: 237-245. 
RANIUS T. 2002. Influence of stand size and quality of tree hollows on saproxylic beetles in Sweden. Biol. Conserv. 103: 85-91.

Root H. T., McGee G. G., Norton R. A. 2007. Arboreal mite communities on epiphytic lichens of the Adirondack Mountains of New York. Northeast. Nat. 14: 425-438.

Schaefer M., Schauermann J. 1990. The soil fauna of beech forests: comparison between a mull and a moder soil. Pedobiologia 34: 299-314.

Seastedt T. R., Reddy M. V., Cline S. P. 1989. Microarthropods in decaying wood from temperate coniferous forests. Pedobiologia 33: 69-77.

Seniczak S., Dąbrowski J., Klimek A., Kaczmarek S. 1998. Effects of air pollution produced by a nitrogen fertilizer factory on the mites (Acari) associated with young Scots pine forests in Poland. Appl. Soil Ecol. 9: 453-458.

Seyd E. L., Seaward M. R. D. 1984. The association of oribatid mites with lichens. Zool. J. Linn. Soc-Lond. 80: 369-420.

Sirra-Pietikäinen A., Penttinen R., Huhta V. 2008. Oribatid mites (Acari: Oribatida) in boreal forest floor and decaying wood. Pedobiologia 52: 111-118.

Skubata P., Duras M. 2008. Do decaying logs represent habitat islands? Oribatid mite communities in dead wood. Ann. Zool. 58: 453-466.

Skubata P., Gurgul B. 2011. Importance of tree hollows for biodiversity of mites (Acari) in the forest reserve „Śrubita” (Carpathian Mountains, south Poland). Biol. Lett. 48: 97-106.

Skubata P., Marzec A. 2013. Importance of different types of beech dead wood for soil microarthropod fauna. Pol. J. Ecol. 61: 543-557.

Skubaza P., Maślak M. 2009. Succession of oribatid fauna (Acari, Oribatida) in fallen spruce trees: Deadwood promotes species and functional diversity. In: Trends in Acarology (SABELIS M. W., BRUIN J. Eds), pp. 123-128, Springer Dordrecht, The Netherlands.

SkubaŁa P., SokoŁowsKa M. 2006. Oribatid fauna (Acari, Oribatida) in spruce fallen trees in the Babia Góra National Park. Biol. Lett. 43: 243-248.

SMRŽ J. 2010. Nutritional biology of oribatid mites from different microhabitats in the forest. In: Trends in Acarology (Sabelis M. W., Bruin J., Eds), pp. 213-216, Springer Dordrecht, The Netherlands.

SMRŽ J., KUČERA T., VAŠKŮ Z. 2015. Food Offer Inside Agroecosystem Soils as an Ecological Factor for Settling Microhabitats by Soil Saprophagous Mites. Acta Univ. Agric. et Silvic. Mendel. Brun. 63: 1565-1574.

Subías L. S. 2004-2015. Listado sistemático, sinonímico y biogeográfico de los ácaros oribátidos (Acariformes: Oribatida) del mundo (excepto fósiles) [Systematic, synonymic and biogeographical check-list of the world's oribatid mites (Acariformes, Oribatida)] (1758-2002). Graellsia 60: 3-305. Updated in March 2015: http://escalera.bio.ucm.es/usuarios/bba/cont/ docs/RO_1.pdf. Cited 10 November 2015 (in Spanish with English summary).

Sylwestrowicz-Maliszewska, Olszanowski Z., BŁoszyK J. 1993. Moss mites (Acari: Oribatida) of pine forests from Poland. Fragm. Faun. 36: 185-199.

TAGUCHI Y. H., Oono Y. 2005. Relational patterns of gene expression via non-metric multidimensional scaling analysis. Bioinformatics 21: 730-740.

Usher M. B., Booth R. G., Sparkes K. E. 1982. A review of progress in understanding the organization of communities of soil arthropods. Pedobiologia 23: 126-144.

Walter D. E., Proctor H. C. 1999. Mites. Ecology, Evolution and Behaviour. CABI Publishing, New York, USA.

WaUthy G. 1982. Synecology of forest soil oribatid mites of Belgium (Acari, Oribatida). III. - Ecological groups. Acta Oecol. 3: 469-494.

Wehner K., Norton R. A., Blüthgen N., Heethoff M. 2016. Specialization of oribatid mites to forest microhabitats - the enigmatic role of litter. Ecosphere 7: e01336.

WeigmanN G. 2006. Oribatid communities in transects form bogs to forests un Berlin indicating the biotope qualities. In: Modern Acarology (Dusbábek F., Bukva V., Eds), vol. 1, pp. 359-364, Academia, Prague and SPB Academic Publishing bv, The Hague. 
Weigmann G. 2006. Hornmilben (Oribatida) [Moss mites (Oribatida)]. In: Die Tierwelt Deutschland und der angrenzenden Meeresteile (DAHL F., Ed.). 76. Teil, pp. 1-520. Goecke \& Evers, Keltern (in German).

Wolf M. M., RocketT C. L. 1984. Habitat changes affecting bacterial composition in the alimentary canal of oribatid mites (Acari: Oribatida). Int. J. Acarol. 10: 209-215.

WundERLE I. 1992. Die Oribatiden-Gemeinschaften (Acari) der verschiedenen Habitate eines Buchenwaldes. Carolinea 50: 79-144.

Appendix I. List of oribatid species recorded in 6 microhabitats in the Silesian Park

\begin{tabular}{|c|c|c|c|c|c|c|c|}
\hline Species & Abbr. & S-L & M & $\mathrm{F}$ & $\mathrm{W}$ & $\mathrm{L}$ & $\mathrm{H}$ \\
\hline $\begin{array}{l}\text { Achipteria }(\text { A.) coleoptrata coleoptrata } \\
\text { (Linnaeus, } 1758)\end{array}$ & & + & & & + & + & \\
\hline $\begin{array}{l}\text { Acrogalumna longipluma longipluma (Berlese, } \\
\text { 1904) }\end{array}$ & & & & + & & + & + \\
\hline Acrotritia ardua ardua (Koch, 1841) & A ard & + & & + & & + & \\
\hline Acrotritia duplicata (Grandjean, 1953) & A dup & + & & & + & & \\
\hline Atropacarus striculus striculus (Koch, 1835) & A str & + & + & + & + & + & \\
\hline $\begin{array}{l}\text { Autogneta }(\text { A.) longilamellata longilamellata } \\
\text { (Michael, 1885) }\end{array}$ & & & + & + & + & & \\
\hline Carabodes (C.) femoralis (Nicolet, 1855) & $\mathrm{C}$ fem & & + & + & & + & \\
\hline Cepheus cepheiformis (Nicolet, 1855) & & + & + & + & & & \\
\hline $\begin{array}{l}\text { Ceratozetes }(C .) \text { gracilis gracilis (Michael, } \\
1884)\end{array}$ & $\mathrm{C}$ gra & + & + & & & + & \\
\hline Chamobates ( C.) cuspidatus (Michael, 1884) & & + & & & & & \\
\hline $\begin{array}{l}\text { Chamobates (Xiphobates) voigtsi (Oudemans, } \\
\text { 1902) }\end{array}$ & & + & & & & & \\
\hline $\begin{array}{l}\text { Conchogneta willmanni willmanni (Dyrdowska, } \\
\text { 1929) }\end{array}$ & C wil & + & + & & & + & \\
\hline Cultroribula bicultrata (Berlese, 1905) & & & + & & & & \\
\hline Damaeus $(D$.$) riparius Nicolet, 1855$ & & + & & & & & \\
\hline $\begin{array}{l}\text { Damaeus (Epidamaeus) bituberculatus } \\
\text { (Kulczynski, 1902) }\end{array}$ & D bit & & & & + & & + \\
\hline Hypochthoniella minutissima (Berlese, 1904) & & + & & & & + & \\
\hline Eupelops sulcatus sulcatus (Oudemans, 1914) & & + & & & & & \\
\hline $\begin{array}{l}\text { Euphthiracarus (E.) cribrarius cribrarius } \\
\text { (Berlese, 1904) }\end{array}$ & & + & + & & + & & + \\
\hline $\begin{array}{l}\text { Euphthiracarus (E.) monodactylus (Willmann, } \\
\text { 1919) }\end{array}$ & & + & & + & + & & + \\
\hline Euzetes globulus (Nicolet, 1855) & E glo & + & & & + & + & \\
\hline Galumna $(G$.$) lanceata (Oudemans, 1900)$ & & + & & & + & & \\
\hline
\end{tabular}




\begin{tabular}{|c|c|c|c|c|c|c|c|}
\hline Species & Abbr & S-L & M & $\mathrm{F}$ & W & $\mathrm{L}$ & $\mathrm{H}$ \\
\hline Gustavia microcephala (Nicolet, 1855) & & + & & & + & + & \\
\hline Hafenrefferia gilvipes (Koch, 1839) & H gil & & + & + & + & & \\
\hline $\begin{array}{l}\text { Heminothrus (Platynothrus) peltifer peltifer } \\
\text { (Koch, 1839) }\end{array}$ & & + & & & + & & \\
\hline Hypochthonius rufulus rufulus Koch, 1835 & & + & + & & & + & \\
\hline $\begin{array}{l}\text { Nothrus anauniensis Canestrini y Fanzago, } \\
1876\end{array}$ & $\mathrm{~N}$ ana & + & + & & & + & \\
\hline Oppia nitens nitens Koch, 1836 & O nit & & & & & & + \\
\hline $\begin{array}{l}\text { Oppiella }(O .) \text { besucheti Mahunka y Mahunka- } \\
\text { Papp, } 2000\end{array}$ & & & & + & + & & + \\
\hline Oppiella $(O$.$) nova nova (Oudemans, 1902)$ & O nov & + & + & + & & & \\
\hline Oribatella $(O$.$) calcarata ($ Koch, 1835) & & + & + & + & & & \\
\hline Oribatula $(O$.$) tibialis tibialis (Nicolet, 1855)$ & & & + & & & & \\
\hline $\begin{array}{l}\text { Oribatula (Zygoribatula) exilis exilis (Nicolet, } \\
1855)\end{array}$ & & & + & & & & \\
\hline Pantelozetes paolii (Oudemans, 1913) & & + & & & & & \\
\hline $\begin{array}{l}\text { Phthiracarus (Archiphthiracarus) globosus } \\
\text { (Koch, 1841) }\end{array}$ & P glo & + & & & + & & \\
\hline Phthiracarus (P.) ferrugineus (Koch, 1841) & $P$ fer & + & + & + & + & + & \\
\hline Phthiracarus (P.) longulus (Koch, 1841) & & + & & + & + & + & \\
\hline $\begin{array}{l}\text { Pilogalumna crassiclava crassiclava (Berlese, } \\
\text { 1914) }\end{array}$ & & & & + & & + & \\
\hline Punctoribates (P.) punctum (Koch, 1839) & & + & + & & & & + \\
\hline $\begin{array}{l}\text { Quadroppia (Coronoquadroppia) michaeli } \\
\text { michaeli Mahunka, } 1977\end{array}$ & Q mic & & + & & + & + & \\
\hline Quadroppia (Q.) maritalis Lions, 1982 & & & + & & & & \\
\hline $\begin{array}{l}\text { Quadroppia (Q.) quadricarinata (Michael, } \\
\text { 1885) }\end{array}$ & Q qua & & + & & + & & \\
\hline Ramusella (R.) clavipectinata (Michael, 1885) & & & + & & & & + \\
\hline $\begin{array}{l}\text { Ramusella (Rectoppia) fasciata fasciata (Paoli, } \\
\text { 1908) }\end{array}$ & $\mathrm{R}$ fas & & & & & & + \\
\hline Rhinoppia (R.) obsoleta obsoleta (Paoli, 1908) & R obs & + & & & & & \\
\hline Rhinoppia (R.) subpectinata (Oudemans, 1900) & R sub & + & & & & & \\
\hline Scheloribates $(S$.$) pallidulus (Koch, 1841)$ & & & + & + & + & + & \\
\hline $\begin{array}{l}\text { Subiasella (Lalmoppia) quadrimaculata } \\
\text { (Evans, 1952) }\end{array}$ & $\mathrm{S}$ qua & & + & & & & + \\
\hline Suctobelba discrepans Moritz, 1970 & & & + & & & & \\
\hline Suctobelba lapidaria Moritz, 1970 & & & + & & & & \\
\hline $\begin{array}{l}\text { Suctobelbella (Flagrosuctobelba) baloghi } \\
\text { (Forsslund, 1958) }\end{array}$ & & + & + & & & & \\
\hline
\end{tabular}




\begin{tabular}{|c|c|c|c|c|c|c|c|}
\hline Species & Abbr & S-L & $\mathrm{M}$ & $\mathrm{F}$ & $\mathrm{W}$ & $\mathrm{L}$ & $\mathrm{H}$ \\
\hline $\begin{array}{l}\text { Suctobelbella (Flagrosuctobelba) nasalis } \\
\text { (Forsslund, 1941) }\end{array}$ & & + & & & & & \\
\hline $\begin{array}{l}\text { Suctobelbella (S.) longicuspis longicuspis Jacot, } \\
1937\end{array}$ & & + & + & & & & \\
\hline Suctobelbella $(S$.$) perforata (Strenzke, 1950)$ & & & + & & & & \\
\hline Suctobelbella (S.) similis (Forsslund, 1941) & & + & + & & & & \\
\hline $\begin{array}{l}\text { Suctobelbella }(S .) \text { subtrigona (Oudemans, } \\
1900)\end{array}$ & & + & + & & & & \\
\hline Tectocepheus alatus Berlese, 1913 & $\mathrm{~T}$ ala & & + & + & & & \\
\hline Tectocepheus minor Berlese, 1903 & & + & & & & & \\
\hline Tectocepheus velatus sarekensis Trägårdh, 1910 & & & & & + & & \\
\hline Tectocepheus velatus velatus (Michael, 1880) & T vel & + & + & + & + & + & \\
\hline Trichoribates (T.) novus novus (Sellnick, 1928) & & & + & & + & & \\
\hline Tritegeus bisulcatus Grandjean, 1953 & & + & & & + & & \\
\hline Xenillus $(X$.$) tegeocranus (Hermann, 1804)$ & $\mathrm{X}$ teg & + & + & + & & + & + \\
\hline
\end{tabular}

$\mathrm{S}-\mathrm{L}=$ soil-litter layer; $\mathrm{M}=$ moss $; \mathrm{F}=$ fungus; $\mathrm{W}=$ dead wood; $\mathrm{L}=$ leaves $\mathrm{H}=$ tree hollow 